\title{
The future direction of pit lakes: part 1, Research needs
}

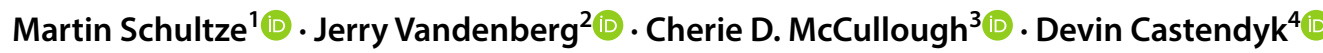

Received: 16 October 2021 / Accepted: 9 February 2022 / Published online: 2 March 2022

(c) The Author(s) 2022

\begin{abstract}
Pit lakes are common features of open pit mining and can present significant risks, and yet can also provide beneficial end use opportunities. Many processes that influence the magnitude of these risks and opportunities remains poorly understood, which presents a challenge to pit lake closure and management. In this two-part manuscript, four pit lake subject matter experts from Germany, Canada, Australia, and the USA recommend focus areas for researchers (Part 1) and strategies to structurally improve the practice of pit lake closure for mining industry regulators and corporate sustainability officers (Part 2). In this Part 1, we recommend nine research areas, organized by order of physico-chemical and ecological complexity, where greater understanding of fundamental pit lake processes would lead to improved pit lake management and reuse. Our intent is to guide the direction of emerging and future pit lake research by academic and industry research teams, with funding and oversight from industry and government.
\end{abstract}

Keywords Sustainability $\cdot$ Expert commentary $\cdot$ Hydrology $\cdot$ Geochemistry $\cdot$ Ecology $\cdot$ Socio-economy

\section{Introduction}

Pit lakes remain as final landforms of the post-mining landscape in many instances of open pit mining, also called cut mining and surface mining. Depending on the country and

Martin Schultze

martin.schultze@ufz.de

$\triangle$ Jerry Vandenberg

jerry@vws.ltd

$\triangle$ Cherie D. McCullough

cmccullough@minelakes.com

$\triangle$ Devin Castendyk

devin_castendyk@golder.com

1 Helmholtz-Zentrum für Umweltforschung GmbH - UFZ, Brueckstrasse 3a, 39114 Magdeburg, Germany

2 Vandenberg Water Science Ltd, 7441 Hawk Rd, Kelowna, Canada

3 Mine Lakes Consulting, PO Box 144, 6919 Joondalup DC, WA, Australia

4 Golder Associates, 7245 W Alaska Dr., Suite 200, 80226 Lakewood, CO, USA local vernacular, these legacies may also be known as mine pit lakes, mine lakes, void lakes, or end pit lakes.

Poorly planned pit lakes often present risks to the environment and human health and safety (Doupé and Lymbery 2005; Hinwood et al. 2012), such as slope instability, drowning, entrapment, falls hazards, and poor water quality (McCullough and Lund 2006). Poor water quality may result from: (i) the action of acidic and metalliferous drainage (AMD) with low $\mathrm{pH}$ and/or elevated contaminant concentrations associated with sulfide mineral oxidation, (ii) the addition of neutral or basic mine drainage with elevated concentrations of contaminants (e.g. Se, As), which are mobile at neutral to basic $\mathrm{pH}$, (iii) saline conditions resulting from evapoconcentration, and/or, (iv) elevated nitrogenous concentrations as toxicants and nutrients from dissolution of blasting agents. Conversely, pit lakes that are well-planned and managed have the potential to become beneficial end use resources. Such end uses include ecological reserves, recreation areas, water supplies for irrigation or stock water, reservoirs for cooling water and energy production, and treatment facilities for contaminated mine water (McCullough et al. 2020). 
Over the past four decades, pit lake research has evolved from isolated single-discipline studies (e.g. Campbell and Lind 1969; King et al. 1974; Parsons 1964; Stundl 1937) to a more integrated and multidisciplinary field. To mitigate or prevent risks and proactively plan for beneficial end uses, an interdisciplinary understanding of many aspects of pit lakes including geology, hydrogeology, hydrology, hydrodynamics, inorganic geochemistry, microbial ecology, biogeochemistry, ecology (avian, aquatic and terrestrial), mining engineering, socioeconomic aspects, and the many dynamic relationships among these disciplines is required. Several recent research compilations outline the state of knowledge and best practices for pit lake monitoring, numerical modelling, and management. However, data gaps exist in fundamental aspects of pit lakes to advance the ecologically and socially sustainable closure practices mandated by companies and their stakeholders (Castendyk and Eary 2009; Gammons et al. 2009; Geller et al. 2013; McCullough 2011; Oldham 2014; Vandenberg and McCullough 2017).

In this Part 1 of a two-part series, we highlight key knowledge gaps and future research needs associated with the long-term closure of metal and coal mine pits. Although mining associated with other resources (e.g. oil sands, aggregate) may also generate pit lakes, metal and coal mine deposit types comprise most of the pit lakes that require substantial rehabilitation efforts due to acidification by relatively high sulfide mineral concentrations associated with their geologies (Eary and Castendyk 2013; Friese et al. 2013). In contrast, sand, gravel and other aggregate pit lakes typically have low sulfide content and are more benign in terms of water chemistry (Matern et al. 2019; Søndergaard et al. 2018), and are not considered herein. Oil sands pit lakes comprise unique organic chemical compositions relative to other pit lakes (Dompierre et al. 2016; Morandi et al. 2020) and are therefore also not explicitly considered herein. That said, many of the data gaps and study needs identified here are relevant to the aggregate and oil sands industries.

The authors of this paper represent a cross-section of experienced pit lake researchers, managers, and mine closure planners from around the world (Germany, Canada, Australia, and USA) who have worked in and across academia, government, and private industry. Based on our collective experiences of $\approx 100$ years of practice and relevant literature, we discuss nine topics of pit lakes that we believe constitute key data gaps. For each area, we then identify potential paths forward to address research needs or open research questions. The intent of this paper is to provide a catalyst for researchers and funding agencies by identifying the research topics that would be most useful for advancing pit lake understanding and generating successful end uses. Our hope is to transform pit lakes into post-mining assets with acceptable risks, which become beneficial to our global cultures and environments, and which promote industry's social license to mine.

\section{Key Research Needs}

\section{Understanding Interactions between Pit Lakes and Groundwater}

The typically high connectivity between pit lakes and groundwater is a particular property that distinguishes pit lakes from other lake types (Brown and Trott 2014). Pit lakes are too young and often too oligotrophic to have accumulated thick, sealing layers of organic sediment along the pit floor (although as discussed in Part 2 (Vandenberg et al. 2022), disposed tailings can serve this purpose), and pit walls often cut deeply into alluvial aquifers and fractured bedrock. Metalliferous ore bodies are often located along geologic structures that form preferential flow paths for regional groundwater. In addition, blasting used in the mining process often generates fractures that may penetrate several meters into the pit wall, resulting in a "damaged rock zone" with a notably higher hydraulic conductivity relative to the interior host rock. Pit lakes in former lignite mines in Europe (e.g. Schultze et al. 2013b; Widera 2016) and Australia (Varma 2002) often intersect multiple stratigraphic units containing alternating layers of aquifers and aquitards, such that the pits form vertical connections between one or more aquifers. In contrast to the thick layers of sediment or impermeable bedrock that often form aquitards at the benthic floor of natural lakes, pit lakes generally lack such a benthic layer and are well connected to adjacent aquifers. Even artificial water bodies such as reservoirs are often sealed with engineered materials to minimize seepage losses or are located in low groundwater transmittivity sediments. The broad catchment area of many natural lakes and constructed reservoirs also supplies fine grained sediments to a reservoir, the deposition of which will slowly decrease the hydraulic conductivity of the benthic layer over time. Pit lakes typically have relatively smaller catchment areas and may show little change in benthic-layer thickness or flow properties over time. How these factors and processes affect short and long-term pit lake-groundwater interactions remains unclear.

The long-term pit lake water balance is critical to understanding many risks that a pit lake can pose to downgradient streams, lakes, and aquifers. The steady-state water level defines the final watershed area, the amount of aerially-exposed, sulfidic wall rock, and the area of the riparian and littoral zones. These factors directly affect mine closure planning (Sánchez-España et al. 2014; Werner et al. 2001). 
Despite its importance, little research has been undertaken on the fundamental interactions between pit lakes and groundwater (Neumann et al. 2013; Seebach et al. 2010), and several issues related to these interactions remain poorly understood (Oldham et al. 2019), such as:

- How long will it take to form a low-hydraulic-conductivity, benthic layer that reduces hydraulic connectivity to adjacent aquifers? How will any materials placed into the pit void alter groundwater interaction locations and flow rates? This question is particularly pertinent to pit lakes that will contain mine waste or will be used as a treatment site for contaminated water or tailings.

- Where does groundwater enter and leave the pit lake-in the upper layers (e.g. the epilimnion), or in the deeper layers (e.g. the hypolimnion or monimolimnion)? What is the density (e.g. temperature and salinity) and chemical load of groundwater entering the lake with respect to receiving water layers within the lake? Both topics directly influence the physical (e.g. well mixed vs. perennially stratified) and chemical (e.g. redox conditions) state of the lake.

- How do groundwater inflow and outflow rates change over time in response to the rising cone-of-depression plus climate-driven variations in the regional water table? Are there seasonal changes in discharge intensity and/or the position (vertical and spatial) of groundwater exchange?

- What are the flow paths of the groundwater (into and out of the pit) and what are the residence times in different aquifers present along these flow paths? The flow path is particularly important where there are karst systems (Lee 1996), sulfide-rich, acid-generating aquifers upgradient of the filling pit (Schafer et al. 2020), or fractured bedrock or other aquifers with high hydraulic heterogeneity and anisotropy.

These questions are very relevant for developing sustainable planning and long-term management of pit lakes for both hydrogeological and water quality aspects (McCullough et al. 2011). As an example, the use of pit lakes for sub-aqueous mine waste disposal (discussed in Part 2; Vandenberg et al. 2022) may present risks to downgradient aquifers without a better understanding of the interaction between disposed waste, its pore water, and groundwater discharge as a function of pit lake elevation. In some cases, study methods are already available (Lewandowski et al. 2015; Rosenberry et al. 2015; Vandenberg et al. 2016). Detailed field investigations need to be conducted, and hydrogeological and limnological studies should be coupled to better estimate the effect of hydrogeology on lake physics, mixing and water quality.

\section{Defining the Role of Pit Lakes Within the Hydrology and Geochemistry of Watersheds}

Pit lakes are fundamental components of the post-mining landscape. Hydrologic and hydrogeologic processes (e.g. surface and groundwater flows and evaporation) (Younger 2002), biogeochemical processes (e.g. mobilization, transport, precipitation, or decay of chemicals) and ecological processes (e.g. wildlife feeding and breeding habitat) (Lund et al. 2013) can all continue past the pit void perimeter into the broader catchment and post-mining landscape. Where pit lakes infrequently intercept regional surface waters, they can contribute or diminish flows in these natural waterways (McCullough 2021). Similarly, where pit lakes more commonly intercept groundwaters, these resources may also be depleted as either through-flow or as terminal sinks (McCullough et al. 2013). Such terminal sinks may be used beneficially to intercept contaminated groundwater, but at the expense of regional aquifer recharge.

Currently, pit lake research still presents gaps as to which physico-chemical processes are essential to broader landscape connections, in particular, how can pit lake closure planning mitigate risks associated with these processes? For instance, how do catchment water inflows influence longterm pit lake quality (McCullough et al. 2012; McCullough and Schultze 2018), both in terms of long-term geochemical evolution and more poignantly in terms of remediation of poor water quality?

As a corollary, the influence of pit lake discharges on regional surface and ground water quality remains complex due to the interaction of AMD-derived elements (e.g. Fe, $\mathrm{Al}$, trace metals/metalloids) with organic compounds. Additional complexity may result from eutrophication mediated by microbial processes (Kumar et al. 2016; Junge and Schultze 2016; Schultze et al. 2013b).

Quantification of these bio-geochemical processes is challenging but often still necessary for informed decision making. Similarly, the biogeochemical interactions along flow paths in the post-mining landscape and downstream mainly requires improved modelling instruments.

\section{Evaluating the Role of Microorganisms in Contaminant Removal}

The important role of microorganisms in biogeochemical processes like pyrite oxidation and sulfate reduction, and the relevance of these processes for water quality in mining-influenced water bodies has been well known for many decades. However, many details of specific reactions performed by specific microorganisms are still not yet well understood, e.g.: 
- Why do benthic phototrophs precipitate hydrozincite well in one location but not in another, although all basic conditions are the same? Are the formed minerals stable over time, or will they be dissolved again by later microbial activity, such as decay of organic matter, including the remaining biomass of the above-mentioned autotrophs?

- What are the typical (net) rates of sulfate reduction in aquifers and pit lake sediments that can be used to predict self-neutralization (Opitz et al. 2020; Sienkiewicz and Gąsiorowski 2017), and how can we estimate them reliably for mine closure planning?

- What general characteristics of organic compounds lend themselves to pit lake sulfate reduction amendments (Neculita et al. 2007)?

- How does temperature influence microbially-mediated remediation processes? Are processes faster in warmer and slower in colder temperatures to such a degree that cold-climate pit lakes may not be remediated by microbial processes (Luek et al. 2017)?

- Are intermediate sulfide compounds, thiosulfates, a product of incomplete oxidation or incomplete reduction, and what is the role of microbes in these reactions?

- When adding a labile carbon source to a pit lake for the purpose of stimulating sulfate reduction, what is the best strategy to anticipate and minimize hydrogen sulfide gas production?

- Do inoculants accelerate remediation initiation rates or provide a more optimal microbial community?

Fundamental mechanistic understanding is needed to apply microbial contaminant removal at large scales. While an engineering approach may argue for an "if you build it, they will come" approach to microbes, detailed understanding of how to produce the right physicochemical conditions to generate a microbial ecosystem that targets specific contaminants would surely yield more predictable and reliable treatment.

In studies of in-situ treatment options, the question of longevity typically remains unanswered. If the constituents of concern are precipitated or adsorbed onto mineral surfaces, will they remain stably bound, or will they be released from sediment when conditions are no longer artificially manipulated? After treatments conclude, can sustained catchment loading maintain the necessary redox conditions?

In many experimental systems, nutrients are added to pit lakes to promote algae growth and uptake of metals. In these cases, is there a danger of irreversibly eutrophying a lake (Axler et al. 1998; Kumar et al. 2016)?

\section{Assessing Ecotoxicology and Biomagnification}

The effect of microbiota on pit lake water quality, particularly under eutrophic conditions, has been reasonably well studied across a variety of scales in recent years (Wen et al. 2015). However, risks of pit lake water quality to both microbiological communities and higher organisms is much less well understood, including the effects of biomagnification within and beyond the pit lakes, e.g. by piscivorous birds or mammals (McCullough and Vandenberg 2020). Such risk studies are largely limited to screening-level assessments of pit lake water ecotoxicology (McCullough and Sturgess 2020; Nicholson et al. 2013). There remains little information on how contaminant mixtures might interact to increase or decrease toxicity, including the role of $\mathrm{pH}$, e.g. through metal speciation (Neil et al. 2009). In particular, there is little information on the effects of mining-derived mixtures of hardness, salinity, and sulfate toxicity (Mooney et al. 2020; van Dam et al. 2014).

\section{Assessing the Value of Littoral and Riparian Zones}

Although catchment vegetation is known to be important to the ecological functioning of pit lakes, substantial gaps remain regarding benefits to native and other representative biotic measures of regional diversity and ecosystem function, such as riparian vegetation (van Etten 2011). This is especially true for pit lake catchments receiving contributions from significant lotic systems (Lund et al. 2013). The relative importance of riparian and littoral communities to broader catchment vegetation is, nevertheless, not well understood (Lund and McCullough 2011; Lund et al. 2013). How riparian and littoral vegetation adapt to pit lake water quality issues such as low $\mathrm{pH}$, elevated contaminant concentrations, or salinity is also a complication for many pit lake ecosystems compared to natural systems where communities have evolved alongside ambient conditions (Bylak et al. 2019; Luek and Rasmussen 2017).

The littoral zone of lakes is an essential habitat for many species and for the entire lake ecosystem. It is the lake compartment with the highest biodiversity (Vadeboncoeur et al. 2011). Together with the riparian zone, it forms an ecotonal bridge between aquatic and terrestrial ecosystems (Lund et al. 2013). Furthermore, the littoral zone is the location of important biogeochemical processes (Kleeberg et al. 2006). However, many pit lakes have high relative depth (Schultze et al. 2013a) and only a small littoral zone. There is very little research on the role and importance of the littoral and the riparian zone of pit lakes, leaving many open questions like:

- What are the essential processes occurring in the littoral and riparian zone for both the pit lake ecosystem and the 
ecosystem of the post-mining landscape, and do these processes require essential species to be present?

- What are the typical time scales for establishing these keystone species? Do these essential species need to be supported within the remediation process, and what is the potential for natural succession to create a fully functioning community?

- Do riparian zones of pit lakes have similar potential of buffering inputs of contaminants from neighboring contaminated sites (e.g. leaking tailings ponds) as known for the transport of nutrients from agricultural areas into streams (Cole et al. 2020)?

- If unmined land is to be converted to littoral zone to support a pit lake, is it worth the cost, effort and loss of terrestrial resources?

- Is there a general principal for optimal size (or percentage of lake surface area) of the littoral and riparian zones for fulfilling their ecological role and/or accelerating lake closure? Do other general principles for natural lake morphology and hypsography, e.g. pertaining to euphotic depth, hold for pit lakes?

While various 'rules of thumb' proportions have been proposed for the littoral zone, there is little fundamental science underpinning these proportions. Emulating a natural analog lake environment is an ideal objective, but is rarely feasible within the post-mining landscape.

Understanding the functioning and roles of the littoral and riparian zones is essential for proper design of the final shape of the pit lake basin and its vicinity. Inclusion of littoral and riparian zones also has implications for safety, e.g. landslide prevention. Due to the engineering practicality and cost limitations imposed by material handling for pit void rehabilitation, such changes should be considered early in the mine planning process.

\section{Determining the Influence of Pit Lakes on Post- mining Ecosystems}

Ecologically, the values of pit lakes to regional biodiversity and ecological sustainability are not well understood, and quantitative knowledge on the interaction of terrestrial and aquatic organisms within pit lakes is virtually absent, except for some toxicological studies. This topic still requires more fundamental research.

Nutrient cycling in pit lakes is often different from natural lake analogues in terms of the many differences of: pit lake shape; percentage of vegetated area and role of vegetation within the broader watershed; the aforementioned hydrologic/hydrogeologic connections; residual mine chemistry; and ecological especially microbial (e.g. planktonic ecology) colonization (Yokom et al. 1997). Pits may initially have excess dissolved reactive nitrogen due to blasting residuals, but little dissolved organic carbon or dissolved reactive phosphorous due to relatively small catchments and geochemical precipitation processes. How nutrients are imported, transformed, stored, or exported from pit lakes is poorly understood. In particular, the individual and combined roles of iron and sulfur may dictate carbon cycling more so than phosphorus and nitrogen, even under eutrophic conditions (McCullough and Lund 2011; Wendt-Potthoff et al. 2012).

Will the sediments of a pit lake act as a sink or as a source and will this reservoir be stable over time? Poorly known details of the flow paths can often be decisive, and can be strongly influenced by hydrological processes and limnophysical conditions (i.e. meromixis vs. holomixis).

There are exceptional opportunities for research on ecological succession processes and for providing controlled sanctuary environments for conservation of endangered aquatic species within pit lakes that are barely realized (D'Souza et al. 2004; Galeotti et al. 2010; Lewin et al. 2015). These ecosystems may approximate natural analogs, or may be substantially different and novel ecosystems (McCullough and van Etten 2011; van Etten et al. 2014). In either case, they may meet equally valid end uses, e.g. an engineered upper trophic level as aquaculture with topdown repercussions to the rest of the pit lake food web. Although initial ecological successions in pit lakes may be quite fast, several years of research is still required, including multi-year field studies, because of seasonality and inter-annual variability of weather, hydrological, and other conditions, and since many species have generation times of several years.

The role of ecological corridors (continuous vegetation or waterways as connections) in facilitating colonization is not well understood, particularly in terms of how founder communities might accelerate pit lake ecosystem development. Deliberate introductions of fish as top-down predators may also be important for low-productivity pit lakes, especially under different nutrient regimes (Peterka and Kubečka 2011; Peterka et al. 2011).

Furthermore, substantial gaps remain regarding benefits to native and other representative biotic measures of regional diversity and ecosystem function (Younger et al. 2004). "Pit lake districts" (more than 10 pit lakes within a limited area) are known from Australia, Canada, Czech Republic, Germany, Poland, and the USA (Brenner et al. 1987; McCullough and van Etten 2011; Twaroski and Segroves 2011). However, what percentage of the lakes has to have good water quality to support a desired ecosystem in the surrounding landscape, and which percentage can remain as poor water quality without adversely affecting the broader landscape ecosystem? Some pit lakes show trends 
of passively self-remediating over long time-scales (Opitz et al. 2020; Sienkiewicz and Gąsiorowski 2017), but are we as society prepared to wait that long? As such, this basic ecological question is also a socio-economic one (see further below).

\section{Predicting the Effects of Climate Change on Pit Lakes}

Climate change can influence pit lakes in three predominant ways: (i) alteration of pit lake water balance with changes in precipitation, evaporation, and inflow rates; (ii) altered biogeochemical reaction rates; and (iii) change in how pit lakes interact with surrounding terrestrial ecosystems. Climate change may alter median events but also their variability, including their greatest magnitude, e.g. annual exceedance probability. The first two contribute importantly as source terms to the management issue of water balance and water quality prediction. However, pit lake predictions often do not consider how these source terms will be influenced by climate change. Nonetheless, rather than simply amending empirical model input parameters, an understanding is also required of how and why sensitive hydrological processes and biogeochemical reaction rates are influenced by broader climate change. This understanding should exist not only with researchers, but also with mine planners and industry consultants. As discussed further in Part 2 (Vandenberg et al. 2022), achieving this may require that regulators impose expectations that mining permits and/or closure certifications must consider the effects of climate change in longterm pit lake predictions.

\section{Advancing Pit Lake Models}

In addition to climate change, many variables that are important to mine closure can only be predicted using numerical models. Mine closure planning typically requires the use of several interconnected models to forecast future water quality conditions (Castendyk et al. 2015; Vandenberg et al. 2011). The general approach begins with a projection of meteorology, hydrogeological conditions, and pit geometry at the end of operations. A groundwater and hydrologic model are generated, and ideally a solute transport model is coupled with these where there is significant risk of contaminant transport away from the pit lake. Geochemical models are applied to the lake itself, but are typically not coupled with advective groundwater flow models. Such coupling needs to become the standard but still requires research and development (Vieira Soares and do Carmo Calijuri 2021).

Many pit lake predictions assume fully-mixed conditions throughout the water column. This assumption is virtually always invalid, as most waterbodies deeper than $\approx 5 \mathrm{~m}$ stratify, even if only seasonally, due to external climatic conditions. Pit lakes are especially prone to meromixis (i.e. perennial stratification) owing to their depth, wind sheltering provided by pit walls, and their likelihood of containing elevated solutes that can produce vertical differences in water density (Schultze et al. 2017; Vandenberg and McCullough 2017). Stratification often causes deeper layers to become anoxic (Boland and Padovan 2002). As such, the water chemistry and colonization by organisms will be profoundly affected by vertical changes in redox conditions as well as differential hydrogeologic flow paths interacting with different vertical layers.

Modern limnological pit lake predictions incorporate hydrodynamic models prior to geochemical modelling to explore the depth of mixing and stratification on a seasonal basis (Oldham et al. 2009; Vandenberg et al. 2016). Such models consider the density of inflowing fluids, the geometry of the pit, and daily wind speeds and temperatures, which can all lead to stratification or mixing (Salmon et al. 2017).

Hydrogeochemists use laboratory results from static and kinetic tests to define the representative water quality input for each source (e.g. pit wall runoff, talus, groundwater, and drainage from other mine features) (Castendyk et al. 2015). These inputs are normally assumed to release a constant concentration or constant load to the pit lake over time. Alternatively, kinetic reaction rates may be used to change inflow concentrations over time, such as a concentration decrease caused by the leaching of soluble minerals, or a concentration increase as sulfide minerals begin to oxidize. Using geochemical equilibrium software (Parkhurst and Appelo 2013), inflow waters from a given time step are mixed at representative proportions. The final solution is brought into geochemical equilibrium with selected oversaturated minerals allowed to precipitate, and select undersaturated minerals allowed to dissolve. In some models, trace elements may be allowed to adsorb to or desorb onto the surface of fresh ferrous hydrous oxide minerals, such as ferrihydrite. The water quality and $\mathrm{pH}$ at the end of these reactions are considered to be the water quality of the pit lake at the end of a given time step.

One of the largest gaps in the practice of pit lake prediction is the lack of a user-friendly, transparent, and unified hydrodynamic-geochemical software capable of simultaneously predicting lake physics (stratification) and chemistry (water quality). Although some coupled models exist (Dunbar 2013; Hipsey et al. 2019; Mueller 2021; Prakash et al. 2015; Salmon et al. 2017), they are either: (1) difficult to apply and require extensive datasets and budget, or (2) proprietary with source codes and assumptions that cannot be third-party evaluated. Freely available, easyto-use software, such as PHREEQC (geochemistry) and 
CE-QUAL-W2 (physics) have allowed these tools to be widely applied to pit lakes, so modelers and reviewers alike are familiar with their functionality and limitations. However, a knowledge barrier remains that practically restricts many practitioners to using one or the other of these types of models. The development of a free, unified physical-chemical model would also ensure that fundamental processes are not ignored or omitted during empirical modelling.

\section{Conducting Socio-economic Studies on End-use Opportunities}

In recent years, pit lakes and artificial water bodies have been increasingly described as ecologically, socially, and economically valuable (Brinker et al. 2011; Koschorreck et al. 2020; McCullough et al. 2009a; McCullough et al. 2020; Seelen et al. 2021). For example, like other artificial water bodies, pit lakes can sometimes provide an ecological habitat that is relatively rare in densely populated countries or in arid regions. Such water bodies are often valuable even for common aquatic species (McCullough et al. 2009b; Seelen et al. 2021). Pit lakes may also provide sites for diverse recreational activities (McCullough and Lund 2006; Stephensen and Castendyk 2019; Williams et al. 2020) and may even provide a hub for new tourist destinations, as in the eastern part of Germany (Deshaies 2020; Kühn 2014; Wirth and Lintz 2006). With existing connectivity to electrical networks and an industrial area, another possible use for pit lakes is electrical power generation and/or the use of the pit water for cooling. This potential should stimulate interest in research questions surrounding end-use opportunities.

Pit lakes that develop in arid or water-stressed regions may have higher value for uses such as ecological reserves and recreational areas (McCullough and van Etten 2011). At the opposite extreme, the value of unimpacted groundwater may be many times higher than the value of the impacted water, such that pits may be perpetually pumped to supply fresh water for agriculture or domestic water supplies rather than allowing this water to evaporate and/or evapoconcentrate. Several data gaps exist in the evaluation of proposed mines in arid regions, and we anticipate that future mine permitting processes will evaluate multiple alternative water uses, such as the value of lake water lost to evaporation against the value of groundwater stored in an undisturbed aquifer and usable by future populations.

Of course, there are also risks related to the use of pit lakes. The effect of mine legacies on human health has been poorly understood (Noronha 2004). The influence of poor water quality on users of pit lakes remains a little understood concept, particularly because water quality differs so markedly from that considered by contact guidelines (constituents, mixtures, and concentration ranges) (Hinwood et al. 2012). In addition, the pit walls present significant physical risks from instability, such as shoreline/highwall erosion (McCullough et al. 2019), frequent rockfalls, seismic waves (McCullough and Diaz 2020), and occasional landslides. The probability of these hazards tends to increase as the water table rebounds and hydrostatic pressures within pit walls increase. These physical hazards alone can limit opportunities for post-mining human access and use. Nonetheless, there are some outstanding examples of pit reclamation and reuse that provide incentive for future study (Stephensen and Castendyk 2019).

Therefore, many aspects of pit lake evaluation are still under debate, and there is a lack of data, understanding, and instruments to quantify "objectively" the value of a certain pit lake. Studies on the socio-economic aspects of pit lake formation and use are just beginning (D'Souza et al. 2004; Hähnel 2016). As for lakes in general, quantifying the economic value of pit lakes is still challenging (Börger et al. 2021; O'Sullivan 2005). Data to quantify the intensity of pit lake use, such as numbers of visitors, frequency and length of overnight stays, or fishing success are rarely collected and hard to find if existent. Equally, studies on the value or pit lakes as commercial resources is also only in its infancy (D'Souza et al. 2004). Comprehensive monitoring and research are needed to develop instruments into an interdisciplinary approach including engineers, limnologists, terrestrial ecologists, architects, sociologists, and economists.

\section{Conclusions}

All of these topics merit promotion of pit lake research, but requires action and investment by the mining industry and regulatory authorities. Funding of the research is needed, and data should be made available for research. Accumulated knowledge and experiences from private research need to be published as well. Part 2 (Vandenberg et al. 2022) of this series provides some options on how to implement these requirements.

While we have generated many important and actionable insights over the past 4 decades, but many gaps exist in our knowledge of pit lake development and long-term outcomes. These gaps provide opportunities for a high degree of both breadth and depth in pit lake research. We hope that this article stimulates interest in additional pit lake research and helps identify key topics that must be resolved to achieve these outcomes.

Similarly, there are gaps in management practices that can be remedied at a corporate level, by practitioners and by regulators, as we will address in Part 2 (Vandenberg et al. 2022) of this series. 
Acknowledgements We thank our current and previous research institutions, consulting companies and, very importantly, the supportive mining industry partners that have encouraged and supported our research activities to date. We also acknowledge the contribution of our current and previous research collaborators, including clients, colleagues, and students and those who funded our previous pit lake research. The funding of this Open Access publication was made possible by Projekt DEAL (https://www.projekt-deal.de/about-deal/).

Funding Open Access funding enabled and organized by Projekt DEAL.

Open Access This article is licensed under a Creative Commons Attribution 4.0 International License, which permits use, sharing, adaptation, distribution and reproduction in any medium or format, as long as you give appropriate credit to the original author(s) and the source, provide a link to the Creative Commons licence, and indicate if changes were made. The images or other third party material in this article are included in the article's Creative Commons licence, unless indicated otherwise in a credit line to the material. If material is not included in the article's Creative Commons licence and your intended use is not permitted by statutory regulation or exceeds the permitted use, you will need to obtain permission directly from the copyright holder. To view a copy of this licence, visit http://creativecommons. org/licenses/by/4.0/.

\section{References}

Axler R, Yokom S, Tikkanen C, McDonald M, Runke H, Wilcox D, Bruce C (1998) Restoration of a mine pit lake from aquacultural nutrient enrichment. Restor Ecol 6:1-19. https://doi. org/10.1046/j.1526-100x.1998.00612.x

Boland KT, Padovan AV (2002) Seasonal stratification and mixing in a recently flooded mining void in tropical Australia. Lake Reserv Sci Policy Manage 7:125-131. https://doi. org/10.1046/j.1440-169X.2002.00176.x

Börger T, Campbell D, White MP, Elliot LR, Fleming LE, Garrett JK, Hattam C, Hynes S, Lankia T, Taylor T (2021) The value of blue-space recreation and perceived water quality across Europe: a contingent behaviour study. Sci Total Environ 771:145597. https://doi.org/10.1016/j.scitotenv.2021.145597

Brinker CJ, Symbaluk MD, Boorman JG (2011) Constructing habitat for a sustainable native fisheries in the Sphinx Lake end pit lake system. In: Fourie AB, Tibbett M, Beersing A (eds) Proc, 6th International Conf on Mine Closure. Australian Centre for Geomechanics, Perth, pp 525-534. https://doi.org/10.36487/ ACG_rep/1152_55_Brinker

Brown K, Trott S (2014) Groundwater flow models in open pit mining: can we do better? Mine Water Environ 33:187-190. https://doi. org $/ 10.1007 / \mathrm{s} 10230-014-0270-\mathrm{z}$

Bylak A, Rak W, Wójcik M, Kukuła E, Kukuła K (2019) Analysis of macrobenthic communities in a post-mining sulphur pit lake (Poland). Mine Water Environ 38:536-550. https://doi. org/10.1007/s10230-019-00624-2

Campbell RS, Lind OT (1969) Water quality and aging of strip-mine lakes. J Wat Pollut Control Fed 41:1943-1955

Castendyk DN, Eary LE (eds) (2009) Mine Pit Lakes: Characteristics, Predictive Modeling, and Sustainability. SME, Littleton, CO, USA

Castendyk DN, Eary LE, Balistrieri LS (2015) Modeling and management of pit lake water chemistry 1: theory. Appl Geochem 57:267-288. https://doi.org/10.1016/j.apgeochem.2014.09.004
Cole LJ, Stockan J, Helliwell R (2020) Managing riparian buffer strips to optimise ecosystem services: a review. Agric Ecosyst Environ 296:106891. https://doi.org/10.1016/j.agee.2020.106891

Deshaies M (2020) Metamorphosis of mining landscapes in the lower Lusatian Lignite Basin (Germany): new uses and new image of a mining region. Cah Rech Archit Urbaine Paysagère 7:159-182. https://doi.org/10.4000/craup.4018

Dompierre KA, Lidsay MBJ, Cruz-Hernández P, Halferdahl GM (2016) Initial geochemical characteristics of fluid fine tailings in an oil sands end pit lake. Sci Total Environ 556:196-206. https:// doi.org/10.1016/j.scitotenv.2016.03.002

Doupé RG, Lymbery AJ (2005) Environmental risks associated with beneficial end uses of mine lakes in southwestern Australia. Mine Water Environ 24:134-138. https://doi.org/10.1007/ s10230-005-0084-0

D'Souza G, Miller D, Semmens K, Smith D (2004) Mine water aquaculture as an economic development strategy: linking coal mining, fish farming, water conservation and recreation. J Appl Aquaculture 15:159-172. https://doi.org/10.1300/J028v15n01_08

Dunbar DS (2013) Modeling of pit lakes. In: Geller W, Schultze M, Kleinmann RLP, Wolkersdorfer C (eds) Acidic Pit Lakes - Legacies of Surface Mining on Coal and Metal Ores. Springer, Berlin, pp 186-224

Eary LE, Castendyk DN (2013) Hardrock metal mine pit lakes: occurrence and geochemical characteristics. In: Geller W, Schultze M, Kleinmann RLP, Wolkersdorfer C (eds) Acidic Pit Lakes - Legacies of Surface Mining on Coal and Metal Ores. Springer, Berlin, pp 75-106

Friese K, Herzsprung P, Schultze M (2013) Pit Lakes from Coal and Lignite Mining. In: Geller W, Schultze M, Kleinmann RLP, Wolkersdorfer C (eds) Acidic Pit Lakes - Legacies of Surface Mining on Coal and Metal Ores. Springer, Berlin, pp 42-57

Galeotti DM, McCullough CD, Lund MA (2010) Black-stripe minnow Galaxiella nigrostriata (Shipway 1953) (Pisces: Galaxiidae), a review and discussion. J R Soc West Aust 3:13-20

Gammons CH, Harris LN, Castro JM et al (2009) Creating lakes from open pit mines: processes and considerations, emphasis on northern environments.Can Tech Rep Fish Aquat Sci 2826

Geller W, Schultze M, Kleinmann RL, Wolkersdorfer C (eds) (2013) Acidic Pit Lakes: the Legacy of Coal and Metal Surface Mines. Springer, Berlin

Hähnel L (2016) Restoration, governance and regional development in the south of Leipzig. In: Drebenstedt C, Paul M (eds), Proc, Mining Meets Water - Conflicts and Solutions. Technische Universität Bergakademie Freiberg, Freiberg, pp 740-744. www.imwa. info/docs/imwa_2016/IMWA2016_H\%C3\%A4hnel_81.pdf

Hinwood AL, Heyworth J, Tanner H, McCullough C (2012) Recreational use of acidic pit lakes - human health considerations for post closure planning. J Water Resour Protection 4:1061-1070. https://doi.org/10.4236/jwarp.2012.412122

Hipsey MR, Bruce LC, Boon C, Busch B, Carey CC, Hamilton DP, Hanson PC, Read JS, de Sousa E, Weber M, Winslow LA (2019) A General Lake Model (GLM 3.0) for linking with high-frequency sensor data from the global lake ecological observatory network (GLEON). Geosci Model Dev 12:473-523. https://doi. org/10.5194/gmd-12-473-2019

Junge FW, Schultze M (2016) Open cast mines as river sediment and pollutant sinks - the example Mulde Reservoir (East Germany). In: Drebenstedt C, Paul M (eds) Proc, Mining Meets Water Conflicts and Solutions. Technische Universität Bergakademie Freiberg, Freiberg, pp 159-166. https://www.imwa.info/docs/ imwa_2016/IMWA2016 Junge 166.pdf

King DL, Simmler JJ, Decker CS, Ogg CW (1974) Acid strip mine lake recovery. J Water Pollut Control Fed 46:2301-2315

Kleeberg A, Schubert H, Koschorreck M, Nixdorf B (2006) Abundance and primary production of filamentous green algae Zygogonium 
ericetorum in an extremely acid ( $\mathrm{pH} 2.9)$ mining lake and its impact on alkalinity generation. Freshw Biol 51:925-937. https:// doi.org/10.1111/j.1365-2427.2006.01542.x

Koschorreck M, Downing AS, Hejzlar J, Marcé R, Laas A, Arndt WG, Keller PS, Smolders AGP, van Dijk G, Kosten S (2020) Hidden treasures: human-made aquatic ecosystems harbour unexplored opportunities. Ambio 49:531-540. https://doi.org/10.1007/ s13280-019-01199-6

Kühn R (2014) The Lusatian Lakeland. Archit Urban 48:202-213

Kumar RN, McCullough CD, Lund MA, Larranaga SA (2016) Assessment of factors limiting algal growth in acidic pit lakes-a case study from Western Australia, Australia. Environ Sci Pollut Res 23:5915-5924. https://doi.org/10.1007/s11356-015-5829-0

Lee TM (1996) Hydrogeologic controls on the groundwater interactions with an acidic lake in karst terrain, Lake Barco, Florida. Water Resour Res 32:831-844. https://doi.org/10.1029/96WR00162

Lewandowski J, Meinikmann K, Nützmann G, Rosenberry DO (2015) Groundwater-the disregarded component in lake water and nutrient budgets. Part 2: effects of groundwater on nutrients. Hydrol Process 29:2922-2955. https://doi.org/10.1002/hyp.10384

Lewin I, Spyra A, Krodkiewska M, Strzelec M (2015) The importance of the mining subsidence reservoirs located along the trans-regional highway in the conservation of the biodiversity of freshwater molluscs in industrial areas (Upper Silesia, Poland). Water Air Soil Pollut 226:189. https://doi.org/10.1007/ s11270-015-2445-z

Luek A, Rasmussen JB (2017) Chemical, physical, and biological factors shape littoral invertebrate community structure in coalmining end-pit lakes. Environ Manage 59:652-664. https://doi. org/10.1007/s00267-017-0819-2

Luek A, Rowan DJ, Rasmussen JB (2017) N-P fertilization stimulates anaerobic selenium reduction in an end-pit lake. Sci Rep 7:10502. https://doi.org/10.1038/s41598-017-11095-2

Lund MA, McCullough CD (2011) Restoring pit lakes: factoring in the biology. In: McCullough CD (ed) Mine Pit lakes: Closure and Management. Australian Centre for Geomechanics, Perth, pp $83-90$

Lund MA, van Etten EJ, McCullough CD (2013) Importance of catchment vegetation and design to long-term rehabilitation of acidic pit lakes. In: Brown A, Figueroa L, Wolkersdorfer C (eds) Proc, Reliable Mine Water Technology. International Mine Water Assoc IMWA, Denver, pp 1029-1034. www.imwa.info/docs/ imwa_2013/IMWA2013_Lund_540.pdf

Matern S, Emmrich M, Klefoth T, Wolter C, Nikolaus R, Wegener N, Arlinghaus R (2019) Effect of recreational-fisheries management on fish biodiversity in gravel pit lakes, with contrasts to unmanaged lakes. J Fish Biol 94:865-881. https://doi.org/10.1111/ jfb.13989

McCullough CD (ed) (2011) Mine Pit Lakes: Closure and Management. Australian Centre for Geomechanics, Perth

McCullough CD (2021)Rehabilitation of Lake Kepwari: a previously acidic mine lake in Western Australia. In: Stanley P, Wolkersdorfer Ch, Wolkersdorfer K (eds) Proc, Mine Water Management for Future Generations, IMWA, pp 346-351. www.imwa.info/docs/ imwa_2021/IMWA2021_McCullough_346.pdf

McCullough CD, Diaz A (2020) Integrated closure planning for a high-altitude pit lake in the Peruvian Andes. In: Pope J, Wolkersdorfer C, Sartz L, Weber A, Wolkersdorfer K (eds), Proc, Mine Water Solutions, IMWA, pp 129-134 www.imwa.info/docs/ imwa_2020/IMWA2020_McCullough_129.pdf

McCullough CD, Lund MA (2006) Opportunities for sustainable mining pit lakes in Australia. Mine Water Environ 25:220-226. https://doi.org/10.1007/s10230-006-0136-0

McCullough CD, Lund MA (2011) Bioremediation of acidic and metalliferous drainage (AMD) through organic carbon amendment by municipal sewage and green waste. J Environ Manag 92:24192426. https://doi.org/10.1016/j.jenvman.2011.04.011

McCullough CD, Schultze M (2018) Engineered river flow-through to improve mine pit lake and river values. Sci Total Environ 640 641:217-231. https://doi.org/10.1016/j.scitotenv.2018.05.279

McCullough CD, Sturgess S (2020) Human health and environmental risk assessment for closure planning of the Argyle Diamond Mine Pit Lake. In: Pope J, Wolkersdorfer C, Sartz L, Weber A, Wolkersdorfer K (eds), Proc, Mine Water Solutions, IMWA, pp 187-193. www.imwa.info/docs/imwa_2020/IMWA2020 McCullough_187.pdf

McCullough CD, Vandenberg JA (2020) Studying mine pit lake systems across multiple scales. Mine Water Environ 39:173-194. https://doi.org/10.1007/s10230-020-00678-7

McCullough CD, van Etten EJB (2011) Ecological restoration of novel lake districts: new approaches for new landscapes. Mine Water Environ 30:312-319. https://doi.org/10.1007/s10230-011-0161-5

McCullough C, Hunt D, Evans L (2009a) Sustainable development of open pit mines: creating beneficial end uses for pit lakes. In: Castendyk DN, Eary LE (eds) Mine Pit Lakes: Characteristics, Predictive Modeling, and Sustainability. SME, Littleton, pp 249-267

McCullough CD, Steenbergen J, Te Beest C, Lund MA (2009b) More than water quality: environmental limitations to a fishery in acid pit lakes of Collie, south-west Australia. Proc, IMWA, pp 507-511. www.imwa.info/docs/imwa_2009/IMWA2009_ McCullough.pdf

McCullough CD, Müller M, Eulitz K, Lund MA (2011) Modelling a pit lake district to plan for abstraction Regime Changes. In: Fourie AB, Tibbett M, Beersing A (eds) Proc, 6th International Conf on Mine Closure. Australian Centre for Geomechanics, Perth, pp 581-591. https://doi.org/10.36487/ACG rep/1152 61B McCullough

McCullough C, Kumar N, Lund $\bar{M}$, Newport M, BallotE, Short D (2012) Riverine breach and subsequent decant of an acidic pit lake: evaluating the effects of riverine flow-through on lake stratification and chemistry. In: McCullough CD, Lund MA, Wyse L (eds), Proc, IMWA Congress, pp 533-539. www.imwa.info/docs/ imwa_2012/IMWA2012_McCullough_533.pdf

McCullough CD, Marchand G, Unseld J (2013) Mine closure of pit lakes as terminal sinks: Best available practice when options are limited? Mine Water Environ 32:302-313. https://doi. org/10.1007/s10230-013-0235-7

McCullough CD, van Rooijen A, van Maren B (2019) Processbased shoreline erosion modelling for batter design of a coal mine pit lake. In: Fourie AB, Tibbett M, Beersing A (eds) Proc, 13th International Conf on Mine Closure. Australian Centre for Geomechanics, Perth, pp 75-87. https://doi.org/10.36487/ ACG_rep/1915_07_McCullough

McCullough CD, Schultze M, Vandenberg J (2020) Realizing beneficial end uses from abandoned pit lakes. Minerals 10:133. https:// doi.org/10.3390/min10020133

Mooney TJ, McCullough CD, Jansen A, Candler L, Douglas M, Harford AJ, van Dam R, Humphrey C (2020) Elevated magnesium concentrations altered freshwater assemblage structures in a mesocosm experiment. Environ Toxicol Chem 39:1973-1987. https://doi.org/10.1002/etc.4817

Morandi G, Wiseman S, Sun C, Martin JW, Giesy JP (2020) Effects of chemical fractions from an oil sands end-pit lake on reproduction of fathead minnows. Chemosphere 249:126073. https://doi. org/10.1016/j.chemosphere.2020.126073

Mueller M (2021) PITLAKQ. Version 1.6.0. Hydrocomputing GmbH \& Co. KG, Leipzig, Germany. www.pitlakq.com/index.html, Accessed 27 July 2021

Neculita C-M, Zagury GJ, Bussière B (2007) Passive treatment of acid mine drainage in bioreactors using sulfate-reducing bacteria. $\mathrm{J}$ Environ Qual 36:1-16. https://doi.org/10.2134/jeq2006.0066 
Neil LL, McCullough CD, Lund MA, Evans LH, Tsvetnenko Y (2009) Toxicity of acid mine pit lake water remediated with limestone and phosphorus. Ecotoxicol Environ Safety 72:2046-2057. https://doi.org/10.1016/j.ecoenv.2009.08.013

Neumann C, Beer J, Blodau C, Peiffer S, Fleckenstein JH (2013) Spatial patterns of groundwater-lake exchange - implications for acid neutralization processes in an acid mine lake. Hydrol Proc 27:3240-3253. https://doi.org/10.1002/hyp.9656

Nicholson A, Rudnick D, Williams L, Ortega J (2013) Spatial and temporal assessment of ecological risks at a gold mine pit lake. In: Brown A., Figueroa L, Wolkersdorfer C (eds), Proc, Reliable Mine Water Technology IMWA, pp 59-62. www.imwa.info/docs/ imwa_2013/IMWA2013_Nicholson_527.pdf

Noronha L (2004) Ecosystem approaches to human health and wellbeing: reflections from use in a mining context. Eco Health 1:SU16-SU23. https://doi.org/10.1007/s10393-004-0070-1

Oldham C (2014) Environmental Sampling and Modelling for the Prediction of Long-term Water Quality of Mine Pit Lakes. UWA Publishing, Perth

Oldham C, Salmon U, Hipsey M, Ivey G (2009) Modelling pit lake water quality: coupling of lake stratification dynamics, lake ecology, aqueous geochemistry and sediment diagenesis. In: Castendyk DN, Eary LE (eds) Mine Pit Lakes: Characteristics, Predictive Modeling, and Sustainability. SME, Littleton, pp 127-136

Oldham C, Beer J, Blodau C, Fleckenstein J, Jones L, Neumann C, Peiffer S (2019) Controls on iron(II) fluxes into waterways impacted by acid mine drainage: A Damköhler analysis of groundwater seepage and iron kinetics. Wat Res 153:11-20. https://doi. org/10.1016/j.watres.2018.12.024

Opitz J, Alte M, Bauer M, Schäfer W, Söll T (2020) Estimation of self-neutralisation rates in a lignite pit lake. Mine Water Environ 39:556-571. https://doi.org/10.1007/s10230-020-00692-9

O'Sullivan P (2005) On the value of lakes. In: O'Sullivan P, Reynolds CS (eds) The Lakes Handbook: Lake Restoration and Rehabilitation, vol 2. Blackwell, Malden, pp 3-24

Parkhurst DL, Appelo CAJ (2013) Description of input and examples for PHREEQC version 3: a computer program for speciation, batch-reaction, one-dimensional transport, and inverse geochemical calculations. US Geological Survey

Parsons JD (1964) Comparative limnology of strip-mine lakes. Int Ver für theoretische und angewandte Limnologie: Verhandlungen 15:293-298

Peterka J, Čech M, Draštík V, Jusa T, Jaroslava F, Prchalová M, Kubeck J (2011) Ten years of fish community succession in postmining lake Milada-Chabařovice. In: Rüde RT, Freund A, Wolkersdorfer C (eds), Proc, Mine Water - Managing the Challenges. www.imwa.info/docs/imwa_2011/IMWA2011_Peterka_384.pdf

Peterka J, Kubečka J (2011) Fish in the pit lakes - towards a functional ecosystem. In: Rüde RT, Freund A, Wolkersdorfer C (eds), Proc, Mine Water - Managing the Challenges, pp 537. imwa.info/docs/ imwa_2011/IMWA2011_Peterka_383.pdf

Prakash S, Vandenberg JA, Buchak EM (2015) Sediment diagenesis module for CE-QUAL-W2 Part 2: Numerical Formulation. Environ Model Assess 20:249-258. https://doi.org/10.1007/ s10666-015-9459-1

Rosenberry DO, Lewandowski J, Meinikmann K, Nützmann G (2015) Groundwater-the disregarded component in lake water and nutrient budgets. Part 1: effects of groundwater on hydrology. Hydrol Proc 29:2895-2921. https://doi.org/10.1002/hyp.10403

Salmon SU, Hipsey MR, Wake GW, Ivey GN, Oldham CE (2017) Quantifying lake water quality evolution: coupled geochemistry, hydrodynamics, and aquatic ecology in an acidic pit lake. Environ Sci Technol 51:9864-9875. https://doi.org/10.1021/acs. est. $7 \mathrm{~b} 01432$

Sánchez-España J, Diez Ercilla M, Pérez Cerdán F, Yusta I, Boyce AJ (2014) Hydrological investigation of a multi-stratified pit lake using radioactive and stable isotopes combined with hydrometric monitoring. J Hydrol 511:494-508. https://doi.org/10.1016/j. jhydrol.2014.02.003

Schafer WM, Croall J, Schmidt J (2020) Predicting water quality trends in Lone Tree pit lake, Nevada (USA). Mine Water Environ 39:618-629. https://doi.org/10.1007/s10230-020-00698-3

Schultze M, Boehrer B, Geller W (2013a) Morphology, age, and development of pit lakes. In: Geller W, Schultze M, Kleinmann RLP, Wolkersdorfer C (eds) Acidic Pit Lakes - Legacies of Surface Mining on Coal and Metal Ores. Springer, Berlin, pp 11-17

Schultze M, Hemm M, Geller W, Benthaus FC (2013b) Pit lakes in Germany: hydrography, water chemistry, and management. In: Geller W, Schultze M, Kleinmann RLP, Wolkersdorfer C (eds) Acidic Pit Lakes - Legacies of Surface Mining on Coal and Metal Ores. Springer, Berlin, pp 265-291

Schultze M, Boehrer B, Wendt-Potthoff K, Sánchez-España J, Castendyk D (2017) Meromictic pit lakes: case studies from Spain, Germany and Canada and General Aspects of Management and Modelling. In: Gulati RD, Zadereev ES, Degermendzhi AG (eds) Ecology of Meromictic Lakes. Springer, Cham, pp 235-275

Seebach A, von Rohden C, Ilmberger J, Weise SM, Knöller K (2010) Dating problems with selected mining lakes and the adjacent groundwater body in Lusatia, Germany. Isot Environ Health Stud 46:291-298. https://doi.org/10.1080/10256016.2010.502592

Seelen LMS, Teurlincx S, Bruinsma J, Huijsmans TMF, van Donk E, Lütling M, de Senerpont Domis LN (2021) The value of novel ecosystems: disclosing the ecological quality of quarry lakes. Sci Total Environ 769:144294. https://doi.org/10.1016/j. scitotenv.2020.144294

Sienkiewicz E, Gąsiorowski M (2017) The diatom-inferred pH reconstructions for a naturally neutralized pit lake in south-west Poland using the mining and the combined $\mathrm{pH}$ training sets. Sci Total Environ 605-606:75-87. https://doi.org/10.1016/j. scitotenv.2017.06.171

Søndergaard M, Lauridsen TL, Johansson LS, Jeppesen E (2018) Gravel pit lakes in Denmark: chemical and biological state. Sci Total Environ 612:9-17. https://doi.org/10.1016/j. scitotenv.2017.08.163

Stephensen G, Castendyk D (2019) The reclamation of Canmore Creek - an example of a successful walk away pit lake closure. Min Eng 71(8):20-34

Stundl K (1937) Chemisch-biologische Untersuchung des neuentstandenen Sees bei Neufeld ad Leitha, Burgenland. Int Rev Hydrobiol 34:24-42. https://doi.org/10.1002/iroh.19370340104[In German]

Vadeboncoeur Y, McIntyre PB, Vander Zanden MJ (2011) Borders of biodiversity: life at the edge of the world's large lakes. Bioscience 61:526-537. https://doi.org/10.1525/bio.2011.61.7.7

van Dam RA, Harford AJ, Lunn SA, Gagnon MM (2014) Identifying the cause of toxicity of a saline mine water. PLoS ONE 9:e106857. https://doi.org/10.1371/journal.pone.0106857

van Etten EJ (2011) The role and value of riparian vegetation for mine pit lakes. In: McCullough CD (ed) Proc, Mine Pit Lakes: Closure and Management. Australian Centre for Geomechanics, Perth, pp 91-105

van Etten EJB, McCullough CD, Lund MA (2014) Setting goals and choosing appropriate reference sites for restoring mine pit lakes as aquatic ecosystems: case study from south west Australia. Min Technol 123:9-19. https://doi.org/10.1179/17432863 13Y.0000000051

Vandenberg JA, Herrell M, Faithful JW, Snow AM, Lacrampe J, Bieber C, Dayyani S, Chisholm V (2016) Multiple modeling approach for the aquatic effects assessment of a proposed northern diamond mine development. Mine Water Environ 35:350-368. https://doi. org/10.1007/s10230-015-0337-5

Vandenberg JA, Lauzon N, Prakash S, Salzsauler K (2011) Use of water quality models for design and evaluation of pit lakes. In: 
McCullough CD (ed) Proc, Mine Pit Lakes: Closure and Management. Australian Centre for Geomechanics, Perth, pp 63-82

Vandenberg JA, McCullough CD (2017) Key Issues in Mine Closure Planning for Pit Lakes. In: Bolan NS, Kirkham MB, Ok YS (eds), Spoil to Soil, 1st edit. CRC Press, Boca Raton, pp 175-188

Vandenberg J, Schultze M, McCullough CD, Castendyk D (2022) The Future Direction of Pit Lakes: Part 2, Corporate and Regulatory Closure Needs to Improve Management. Mine Water Environ. (in press)

Varma S (2002) Hydrogeology and groundwater resources of the Collie Basin, Western Australia. Hydrogeological Record Series, HG 5. Water and Rivers Commission, Perth

Wen M, Pelletier C, Norlund K, Wolff GWR, Bertnelot D (2015) Phytoremediation to improve pit lake water quality. In: Fourie AB, Tibbett M, Sawatsky L, van Zyl D (eds) Proc, 10th International Cof on Mine Closure, Australian Center for Geomechanics, Vancouver, pp 995-1010

Wendt-Potthoff K, Koschorreck M, Diez Ercilla M, Sánchez España J (2012) Microbial activity and biogeochemical cycling in a nutrient-rich meromictic acid pit lake. Limnologica 42:175-188. https://doi.org/10.1016/j.limno.2011.10.004

Werner F, Bilek F, Luckner L (2001) Impact of regional groundwater flow on the water quality of an old post-mining lake. Ecol Eng 17:133-142. https://doi.org/10.1016/S0925-8574(01)00061-1
Widera M (2016) Genetic classification of Polish lignite deposits: A review. Intern J Coal Geol 158:107-118. https://doi.org/10.1016/j. coal.2016.03.004

Williams MS, Oyedotun TDT, Simmons DA (2020) Assessment of water quality of lakes used for recreational purposes in abandoned mines of Linden, Guyana. Geol Ecol Landsc 4:269-281. https://doi.org/10.1080/24749508.2019.1633220

Wirth P, Lintz G (2006) Rehabilitation and development of mining regions in eastern Germany-strategies and outcomes. Morav Geogr Rep 14:69-82

Yokom S, Axler R, McDonald M, Wilcox D (1997) Recovery of a mine pit lake from aquacultural phosphorus enrichment: model predictions and mechanisms. Ecol Eng 8:195-218. https://doi. org/10.1016/S0925-8574(97)00010-4

Younger P, Wolkersdorfer C (eds) (2004) Mining impacts on the freshwater environment: technical and managerial guidelines for catchment scale management. Mine Water Environ 23: s2-s80. https://doi.org/10.1007/s10230-004-0028-0

Younger PL (2002) Mine waste or mine voids: which is the most important long-term source of polluted mine drainage. United Nations Environment Programme, Mineral Resources Forum. www.mineralresourcesforum.org/docs/pdfs/younger1102.pdf

Publisher's Note Springer Nature remains neutral with regard to jurisdictional claims in published maps and institutional affiliations. 